\title{
Effect of Climate Change on Air Quality
}

\section{Citation}

Jacob, Daniel J., and Darrel A. Winner. 2009. Effect of climate change on air quality. Atmospheric Environment 43(1): 51-63.

\section{Published Version}

doi:10.1016/j.atmosenv.2008.09.051

\section{Permanent link}

http://nrs.harvard.edu/urn-3:HUL.InstRepos:3553961

\section{Terms of Use}

This article was downloaded from Harvard University's DASH repository, and is made available under the terms and conditions applicable to Other Posted Material, as set forth at http:// nrs.harvard.edu/urn-3:HUL.InstRepos:dash.current.terms-of-use\#LAA

\section{Share Your Story}

The Harvard community has made this article openly available.

Please share how this access benefits you. Submit a story.

Accessibility 


\title{
Effect of climate change on air quality
}

\author{
Daniel J. Jacob ${ }^{\mathrm{a}, *}$, Darrell A. Winner ${ }^{\mathrm{b}}$

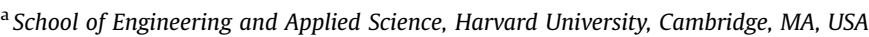 \\ ${ }^{\mathrm{b}}$ Office of Research E Development, U.S. Environmental Protection Agency, Washington, DC, USA
}

Keywords:

Climate change

Air quality

Air pollution meteorology

Ozone

Particulate matter

Mercury

\begin{abstract}
A B S T R A C T
Air quality is strongly dependent on weather and is therefore sensitive to climate change. Recent studies have provided estimates of this climate effect through correlations of air quality with meteorological variables, perturbation analyses in chemical transport models (CTMs), and CTM simulations driven by general circulation model (GCM) simulations of 21st-century climate change. We review these different approaches and their results. The future climate is expected to be more stagnant, due to a weaker global circulation and a decreasing frequency of mid-latitude cyclones. The observed correlation between surface ozone and temperature in polluted regions points to a detrimental effect of warming. Coupled GCM-CTM studies find that climate change alone will increase summertime surface ozone in polluted regions by 1-10 ppb over the coming decades, with the largest effects in urban areas and during pollution episodes. This climate penalty means that stronger emission controls will be needed to meet a given air quality standard. Higher water vapor in the future climate is expected to decrease the ozone background, so that pollution and background ozone have opposite sensitivities to climate change. The effect of climate change on particulate matter (PM) is more complicated and uncertain than for ozone. Precipitation frequency and mixing depth are important driving factors but projections for these variables are often unreliable. GCM-CTM studies find that climate change will affect PM concentrations in polluted environments by $\pm 0.1-1 \mu \mathrm{g} \mathrm{m}^{-3}$ over the coming decades. Wildfires fueled by climate change could become an increasingly important PM source. Major issues that should be addressed in future research include the ability of GCMs to simulate regional air pollution meteorology and its sensitivity to climate change, the response of natural emissions to climate change, and the atmospheric chemistry of isoprene. Research needs to be undertaken on the effect of climate change on mercury, particularly in view of the potential for a large increase in mercury soil emissions driven by increased respiration in boreal ecosystems.
\end{abstract}

(c) 2008 Elsevier Ltd. All rights reserved.

\section{Introduction}

Air pollution results from the combination of high emissions and unfavorable weather. Air quality managers seek to protect public health through emission controls. The resulting improvements in air quality may be modulated by changes in weather statistics, i.e., changes in climate. As we enter an era of rapid climate change, the implications for air quality need to be better understood, both for the purpose of air quality management and as one of the societal consequences of climate change. We review here current knowledge of this issue.

The two air pollutants of most concern for public health are surface ozone and particulate matter, and they are the focus of this review. Ozone is produced in the troposphere by photochemical oxidation of $\mathrm{CO}$, methane, and non-methane volatile organic

\footnotetext{
* Corresponding author.

E-mail address: djacob@fas.harvard.edu (D.J. Jacob).
}

compounds (NMVOCs) by the hydroxyl radical $(\mathrm{OH})$ in the presence of reactive nitrogen oxides $\left(\mathrm{NO}_{x} \equiv \mathrm{NO}+\mathrm{NO}_{2}\right)$. NMVOCs, $\mathrm{CO}$, and $\mathrm{NO}_{x}$ have large combustion sources. Vegetation is a large NMVOC source. Methane has a number of biogenic and anthropogenic sources. $\mathrm{OH}$ originates mainly from atmospheric oxidation of water vapor and cycles in the atmosphere with other hydrogen oxide $\left(\mathrm{HO}_{x}\right)$ radicals. Ozone pollution is in general mostly a summer problem because of the photochemical nature of the source. Ozone production is usually limited by the supply of $\mathrm{HO}_{x}$ and $\mathrm{NO}_{x}$, but can also be NMVOC-limited under highly polluted conditions and outside the summer season. The principal global sink for tropospheric ozone is photolysis in the presence of water vapor. Uptake by vegetation (dry deposition) is also an important sink in the continental boundary layer $(<2 \mathrm{~km})$. Wet deposition is negligible as ozone and its major precursors have low solubility in water. The atmospheric lifetime of ozone ranges from a few days in the boundary layer to weeks in the free troposphere. Ozone and its anthropogenic precursors ventilated from the source continents and transported on hemispheric scales in the free troposphere add 


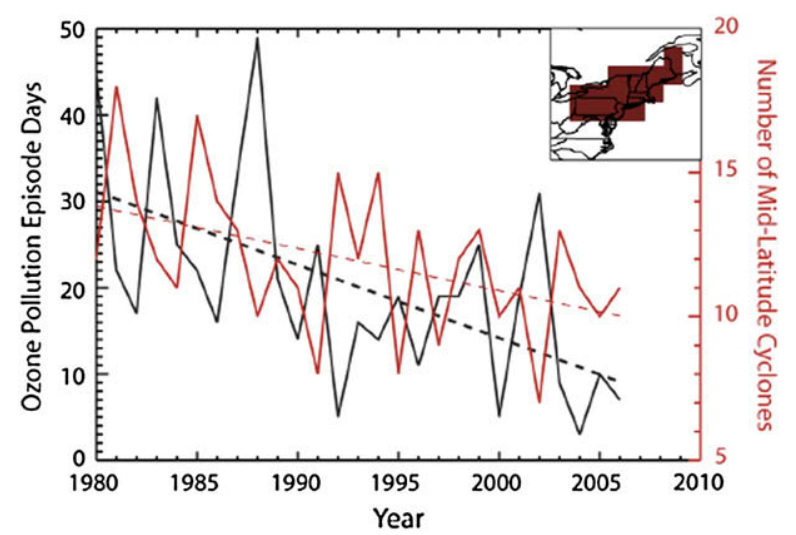

Fig. 1. 1980-2006 trend in the number of ozone pollution episodes (black) and the number of mid-latitude cyclones (red) in the northeastern U.S. in summer (Jun-Aug). Regression lines are also shown. The number of ozone pollution episode days for each summer is determined by averaging maximum daily 8 -h average concentrations from a large number of monitoring sites over $2^{\circ} \times 2.5^{\circ}$ grid squares in the northeastern U.S. (inset), and tallying the number of grid-square days where this average exceeds $80 \mathrm{ppb}$. The number of cyclones is determined for each year from NCEP/NCAR Reanalysis data by tallying the westerly cyclone tracks passing through the eastern U.S.Canada border region $\left(40-50^{\circ} \mathrm{N}, 90-70^{\circ} \mathrm{W}\right)$, which are most important for ventilating the northeastern U.S. From Leibensperger et al. (submitted for publication).

a significant background to surface ozone which is of increasing concern for meeting air quality standards (Holloway et al., 2003; United Nations Economic Commission for Europe (UNECE), 2007).

Particulate matter (PM) includes as principal components sulfate, nitrate, organic carbon, elemental carbon, soil dust, and sea salt. The first four components are mostly present as fine particles less than $2.5 \mu \mathrm{m}$ diameter $\left(\mathrm{PM}_{2.5}\right)$, and these are of most concern for human health. Sulfate, nitrate, and organic carbon are produced within the atmosphere by oxidation of $\mathrm{SO}_{2}, \mathrm{NO}_{x}$, and NMVOCs. Carbon particles are also emitted directly by combustion. Nitrate and organic carbon exchange between the particle and gas phases, depending in particular on temperature. Seasonal variation of PM is complex and location-dependent; in general, PM needs to be viewed as an air quality problem year-round. PM is efficiently scavenged by precipitation and this is its main atmospheric sink, resulting in atmospheric lifetimes of a few days in the boundary layer and a few weeks in the free troposphere (similar to ozone). Unlike for ozone, however, export of PM from the source continents is limited by the precipitation scavenging that usually accompanies continental outflow. The PM background in the free troposphere is thus generally unimportant for surface air quality (Heald et al., 2006; UNECE, 2007). Exceptions are plumes from large dust storms and forest fires which can be transported on intercontinental scales (Prospero, 1999; Forster et al., 2001).

Changes in climate affect air quality by perturbing ventilation rates (wind speed, mixing depth, convection, frontal passages), precipitation scavenging, dry deposition, chemical production and loss rates, natural emissions, and background concentrations. The potential importance of this effect can be appreciated by considering the observed interannual variability in air quality. Fig. 1 shows a 1980-2006 record of the number of exceedances of the U.S. air quality standard for ozone ( $80 \mathrm{ppb}, 8$-h average) in the Northeast. There is a long-term decrease attributable to reductions in anthropogenic emissions ( $\mathrm{NO}_{x}$, NMVOCs), but also a large year-toyear variability due to weather. Ozone is strongly correlated with temperature (Cox and Chu, 1995). The summer of 1988 was the hottest on record in the Northeast and experienced a record high number of exceedances. The summer of 1992 was the coolest in the 1980-2006 record due to the eruption of Mt. Pinatubo and it had a low number of exceedances. The difference in the number of episodes between 1988 and 1992 in Fig. 1 is a factor of 10. If

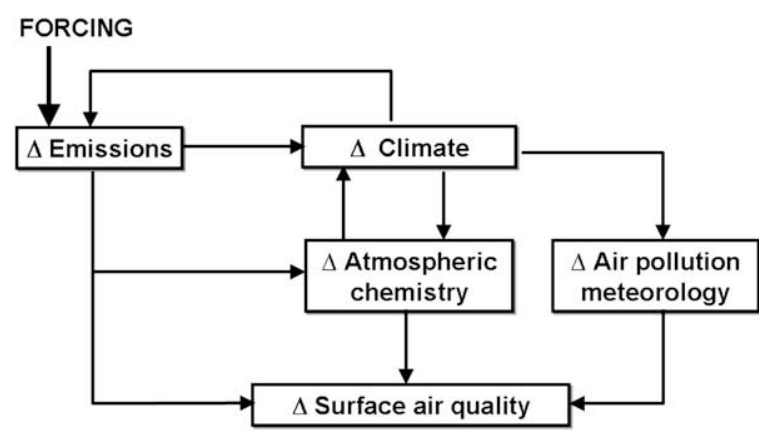

Fig. 2. Effect of climate change on surface air quality placed in the broader context of chemistry-climate interactions. Change is forced by a perturbation to anthropogenic emissions resulting from socio-economic factors external to the chemistry-climate system. This forcing triggers interactive changes $(\Delta)$ within the chemistry-climate system resulting in perturbation to surface air quality.

conditions like 1988 become more frequent as a result of global warming, the implications for air quality could be severe. Similar inferences can be made for Europe, where the summer 2003 heat wave was associated with exceptionally high ozone (Vautard et al., 2005, 2007; Guerova and Jones, 2007; Solberg et al., 2008).

Ozone and PM interact with solar and terrestrial radiation and as such are recognized as important climate forcing agents (Forster et al., 2007). Because of this dual role, the effect of climate change on surface air quality is often framed in the broader context of chemistry-climate interactions (Giorgi and Meleux, 2007; Gustafson and Leung, 2007), as shown diagrammatically in Fig. 2. In this diagram, an external forcing from change in anthropogenic emissions triggers interactive changes within the chemistryclimate-emissions system, and the perturbation to surface air quality is a consequence of these interactive changes. Examples of forcings include anthropogenic emissions of $\mathrm{CO}_{2}$ (driving change in climate), $\mathrm{NO}_{x}$ (driving atmospheric chemistry), or elemental carbon (driving change in climate as well as direct change in air quality). Change in atmospheric chemistry affects air quality (ozone and PM) and climate (ozone, PM, methane). Change in climate affects natural emissions (biosphere, dust, fires, lightning) with implications for air quality. Chemistry-climate interactions involve a number of possible feedbacks, as illustrated in Fig. 2, and these are in general poorly understood (Denman et al., 2007).

We begin this review with a discussion of the effect of climate change on air pollution meteorology, i.e., the regional meteorological conditions that have a general effect on air quality. We then examine and compare results from different approaches used to probe the effects of climate change on ozone and PM air quality: observed correlations with meteorological variables, perturbation studies in chemical transport models (CTMs), and CTM simulations driven by global climate models (commonly called general circulation models or GCMs). We discuss the implications of these results for air quality management, and speculate on the possible implications of climate change for mercury as this is an emerging issue for air quality managers. We present conclusions and finish by suggesting future research directions.

\section{Effect of climate change on air pollution meteorology}

The 4th Assessment Report of the Intergovernmental Panel on Climate Change (IPCC) presents mean regional climate projections for the 21st century from an ensemble of about 20 GCMs (Christensen et al., 2007). Fig. 3 shows the projections of changes in annual mean surface temperature and precipitation in North America, Europe, and Asia for 2080-2099 vs. 1980-1999. The projections are based on the A1B scenario for greenhouse gas emissions from the IPCC Special Report on Emission Scenarios 

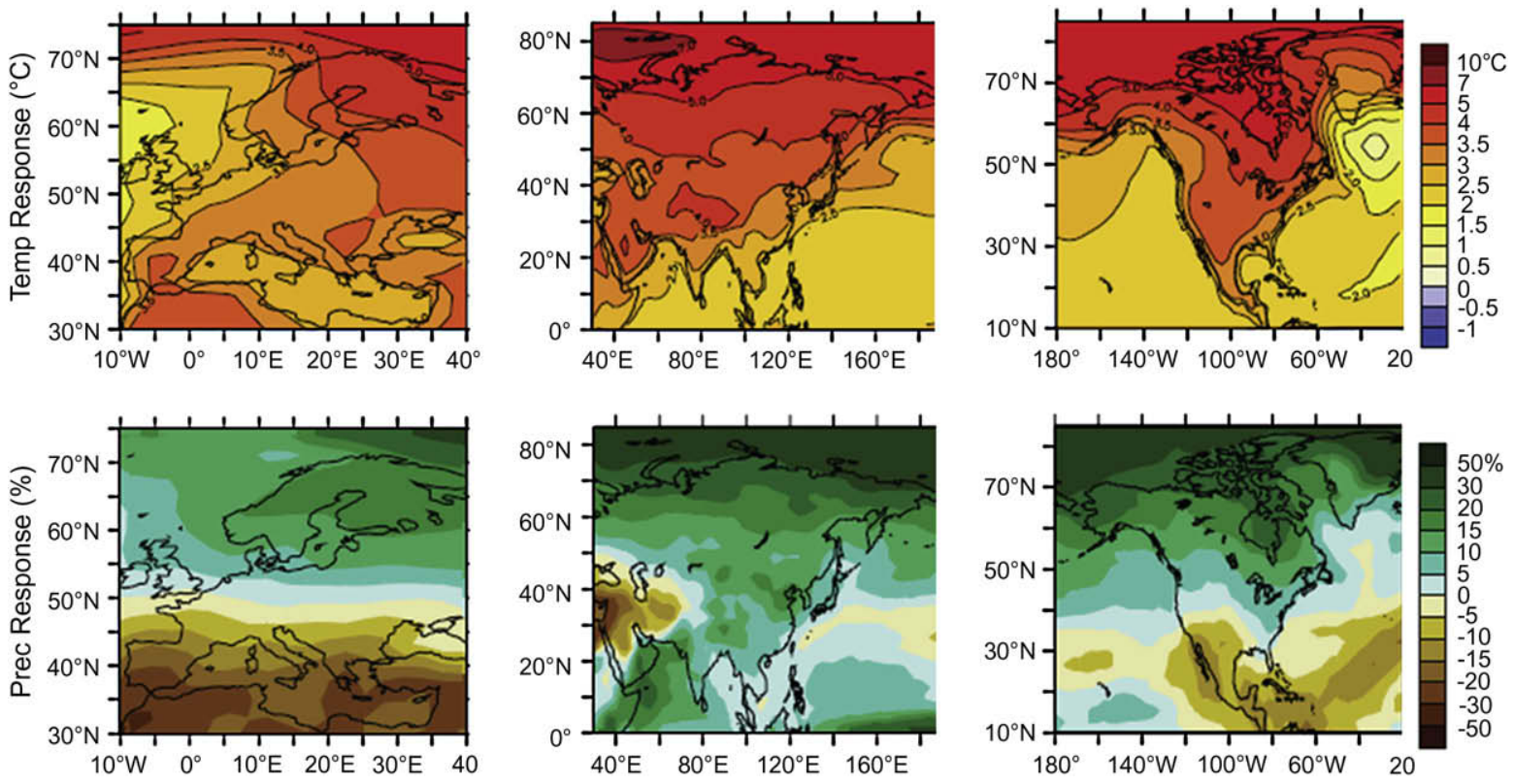

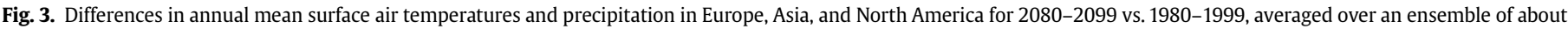
20 GCMs contributing to the IPCC 4th assessment. Adapted from Christensen et al. (2007).

(SRES) [Nakicenovic et al., 2000]. Results from a subset of models indicate that the general spatial patterns of warming and precipitation are similar for the other SRES scenarios, with a $\pm 30 \%$ difference in warming relative to $\mathrm{A} 1 \mathrm{~B}$ depending on the scenario (B1 coolest, A2 warmest). The trends are roughly linear in time, so that the results in Fig. 3 can be interpolated to shorter time horizons. The patterns of Fig. 3 can be viewed as depicting our general understanding of $21 \mathrm{st}$-century climate change, with the caveat that great uncertainty needs to be attached to regional climate projections.

Fig. 3 shows a strong warming over the northern mid-latitude continents, generally increasing in magnitude with increasing latitude. No area experiences cooling. The frequency of heat waves increases in all areas (Christensen et al., 2007). Global precipitation increases slightly due to enhanced evaporation from the oceans but there is considerable regional variability. Precipitation increases in the northern parts of North America and Europe but decreases in the southern parts. It increases in northern Asia but decreases in the Middle East. Models agree in general that high latitudes will become wetter and subtropical latitudes drier. There is a $\sim 10^{\circ}$ transitional band of latitudes centered at about $35^{\circ} \mathrm{N}$ in North America, $50^{\circ} \mathrm{N}$ in Europe, and $25^{\circ} \mathrm{N}$ in East Asia where the model ensemble mean shows little change in precipitation (Fig. 3), but which really reflects disagreement between models as to whether the future climate will be wetter or drier (Christensen et al., 2007).

Other aspects of the hydrological cycle important for air quality (humidity, cloudiness, wet convection) follow qualitatively the precipitation projections of Fig. 3. On a global average basis, specific humidity will increase due to increased evaporation from the oceans, while relative humidity is not expected to change significantly (Held and Soden, 2000), but large regional variations are expected. Forkel and Knoche (2006) and Meleux et al. (2007) draw attention to the expected reduction in cloud cover over southern and central Europe in summer as an important factor promoting ozone formation. Trends in wet convective ventilation vary greatly between models, as the destabilizing effects of higher water vapor and sensible heat in the boundary layer are compensated by the stabilizing effect of latent heat release in the free troposphere (Rind et al., 2001; Wu et al., 2008a). Most GCMs find an increase of lightning in the future climate (Hauglustaine et al., 2005; Brasseur et al., 2006; Wu et al., 2008b), as convection is deeper even if it is less frequent.

Cold fronts spawned by mid-latitudes cyclones are major agents of pollutant ventilation in eastern North America, Europe, and eastern Asia (Cooper et al., 2001; Liu et al., 2003; Li et al., 2005; Ordonez et al., 2005; Leibensperger et al., submitted for publication). Fig. 1 shows a strong interannual correlation between cyclone frequency and the number of high-ozone episodes in the northeastern U.S., illustrating the importance of frontal passages for pollutant ventilation. A consistent result across GCMs is that midlatitude cyclone frequency will decrease in the 21st-century climate and the prevailing cyclone tracks will shift poleward (Lambert and Fyfe, 2006; Christensen et al., 2007). These changes will decrease the frequency of cold frontal passages in polluted mid-latitude regions and hence increase the frequency and duration of stagnation episodes (Mickley et al., 2004; Forkel and Knoche, 2006; Murazaki and Hess, 2006; Wu et al., 2008a). Climatological data for 1950-2000 indeed indicate a decrease and poleward shift of northern mid-latitude cyclones (Zishka and Smith, 1980; McCabe et al., 2001). Leibensperger et al. (submitted for publication) find a decreasing 1980-2006 cyclone trend for eastern North America in summer in the NCEP/NCAR Reanalysis (Fig. 1), as well as in a GCM simulation forced by increasing greenhouse gases, although the trend is not present in the NCEP/ DOE Reanalysis.

The effect of climate change on mixing depth is uncertain. GCM simulations for the 21st century find increases and decreases of mixing depths in different regions with no consistent patterns (Hogrefe et al., 2004; Mickley et al., 2004; Leung and Gustafson, 2005; Murazaki and Hess, 2006; Chen et al., submitted for publication; Lin et al., 2008a; Wu et al., 2008a). Murazaki and Hess (2006) find that trends in mixing depth vary greatly between two versions of the same GCM with different resolutions, implying that the trends are not robust.

\section{Observed correlations of air quality with meteorological variables}

Statistical correlation of pollutant concentrations with meteorological variables has been an active area of study for over three 


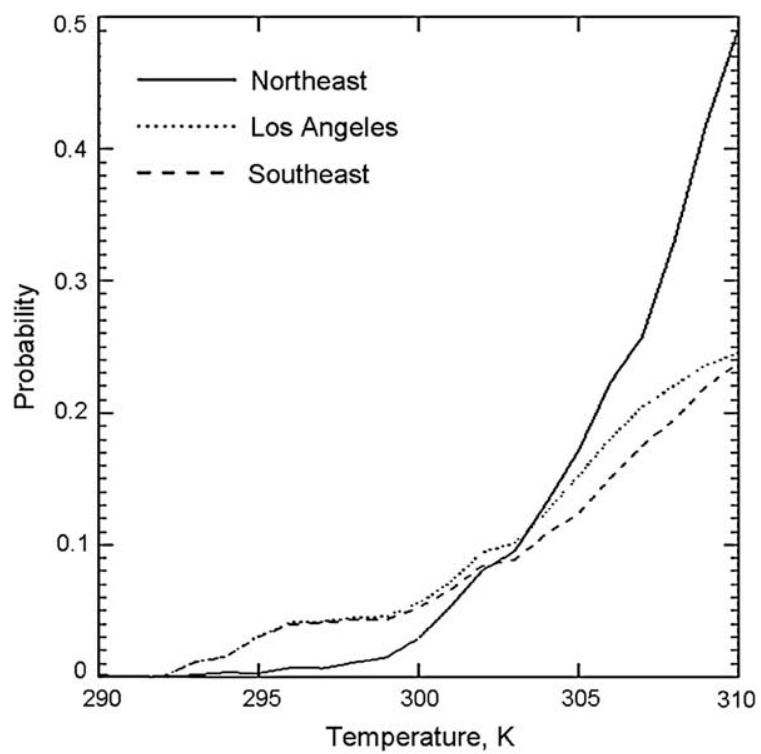

Fig. 4. Observed probability that the maximum daily 8-h average ozone will exceed $80 \mathrm{ppb}$ for a given daily maximum temperature, based on 1980-1998 data. Values are shown for the Northeast U.S., the Los Angeles Basin, and the Southeast U.S. Adapted from Lin et al. (2001).

decades, with three principal purposes: (1) to remove the effect of meteorological variability in analyses of long-term trends of air quality, (2) to construct empirical models for air quality forecasts, and (3) to gain insight into the processes affecting pollutant concentrations. They are useful for our purpose as an observational basis for diagnosing and understanding the sensitivity of pollution to weather.

\subsection{Ozone}

Two recent studies in Europe (Ordonez et al., 2005) and the U.S. (Camalier et al., 2007) present systematic regional-scale analyses of the correlation of ozone with a large number of candidate meteorological variables. Ordonez et al. (2005) find that the dominant predictor variables for ozone at sites in Switzerland in summer are temperature, morning solar radiation, and number of days since last frontal passage. Camalier et al. (2007) find that as much as $80 \%$ of the variance in the maximum daily 8 -h average ozone in the eastern U.S. can be explained by a generalized linear model with temperature (positive) and relative humidity (negative) as the two most important predictor variables. Temperature is most important in the Northeast and relative humidity is more important in the Southeast. Wind speed and direction are important for only a small subset of sites. Studies for different regions indicate that correlations with mixing depth are weak or insignificant (Rao et al., 2003; Ordonez et al., 2005; Wise and Comrie, 2005).

Strong correlation of elevated ozone with temperature is a ubiquitous feature of observations in polluted regions, even in prevailingly hot climates such as the southwestern U.S. (Wise and Comrie, 2005) and Egypt (Elminir, 2005). The correlation is generally limited to polluted conditions, i.e., ozone in excess of about $60 \mathrm{ppb}$; lower ozone concentrations more representative of background show no correlation with temperature (Sillman and Samson, 1995). Fig. 4 shows the probability of ozone exceeding the $80 \mathrm{ppb}$ U.S. air quality standard as a function of daily maximum temperature for three U.S. regions, based on 1980-1998 data. In the Northeast, the probability can double for a $3 \mathrm{~K}$ increase in temperature, illustrating the potentially large sensitivity to climate change.
Table 1

Dependence of surface air quality on meteorological variables. ${ }^{a}$

\begin{tabular}{llc}
\hline Variable & Ozone & PM \\
\hline Temperature & ++ & - \\
Regional stagnation & ++ & ++ \\
Wind speed & - & - \\
Mixing depth & $=$ & -- \\
Humidity & $=$ & + \\
Cloud cover & - & - \\
Precipitation & $=$ & -- \\
\hline
\end{tabular}

a Sensitivities of surface ozone and PM concentrations in polluted regions as obtained from the model perturbation studies reviewed in Section 4. Results are summarized as consistently positive $(++)$, generally positive $(+)$, weak or variable $(=)$, generally negative $(-)$, and consistently negative $(--)$ See text for discussion, including comparison to observed correlations (Section 3).

A few studies have used observed correlations of high-ozone events $(>80 \mathrm{ppb})$ with meteorological variables, together with regionally downscaled GCM projections of these meteorological variables, to infer the effect of 21st-century climate change on air quality if emissions were to remain constant. A major assumption is that the observed present-day correlations, based on short-term variability of meteorological variables, are relevant to the longerterm effect of climate change. Cheng et al. (2007) correlated ozone levels at four Canadian cities with different synoptic weather types, and used projected changes in the frequency of these weather types (in particular more frequent stagnation) to infer an increase in the frequency of high-ozone events by $50 \%$ in the 2050 s and $80 \%$ in the 2080s. Lin et al. (2007) applied the relationship of Fig. 4 for the northeastern U.S. to infer a $10-30 \%$ increase in the frequency of high-ozone events by the 2020s and a doubling by 2050. Wise (in press) projected a quadrupling in the frequency of high-ozone events in Tucson, Arizona by the end of the 21 st century.

\subsection{Particulate matter}

Observed correlations of PM concentrations with meteorological variables are weaker than for ozone (Wise and Comrie, 2005). This reflects the diversity of PM components, the complex coupling of PM to the hydrological cycle, and various compensating effects discussed in Section 4. No significant correlations with temperature have been reported in the literature to our knowledge. Aw and Kleeman (2003) report that peak nitrate concentrations in the Los Angeles Basin decrease with increasing temperature but the data are very noisy. Strong correlation of PM with stagnation is still expected as for ozone and is reported by Cheng et al. (2007) in their study of four Canadian cities. Koch et al. (2003) report a negative correlation of sulfate with cloud cover in Europe over synoptic time scales, which they interpret as reflecting in part the correlation of clouds with precipitation and in part a decrease of $\mathrm{SO}_{2}$ photochemical oxidation, more than compensating for the role of clouds in promoting aqueous-phase production of sulfate. Wise and Comrie (2005) find a negative correlation of PM with relative humidity in the southwestern U.S, reflecting the importance of dust as a PM source in that region.

\section{Perturbation studies in chemical transport models}

A number of studies have investigated the sensitivity of ozone and PM air quality to climate change by perturbing individual meteorological variables in regional CTMs. These studies are useful for understanding the important processes affecting pollutant concentrations, complementing the empirical approach described in Section 3. They also provide a diagnostic tool for more complex GCM-CTM simulations. General results from perturbation studies in the literature are summarized in Table 1 . They are not always consistent with the correlation analyses described in Section 3, 
likely reflecting covariances between meteorological variables as discussed below.

\subsection{Ozone}

Model perturbation studies consistently identify temperature as the single most important meteorological variable affecting ozone concentrations in polluted regions (Morris et al., 1989; Aw and Kleeman, 2003; Sanchez-Ccoyllo et al., 2006; Steiner et al., 2006; Dawson et al., 2007a). This is consistent with the strong observed correlation of ozone pollution episodes with temperature. The model dependence of ozone on temperature is due to two principal factors (Jacob et al., 1993; Sillman and Samson, 1995): (1) the temperature-dependent lifetime of peroxyacetylnitrate (PAN), a major sequestering reservoir for $\mathrm{NO}_{x}$ and $\mathrm{HO}_{x}$ radicals even at high temperatures; and (2) the temperature dependence of biogenic emission of isoprene, a major VOC precursor for ozone formation under high- $\mathrm{NO}_{x}$ conditions. Model slopes $\left(\partial\left[\mathrm{O}_{3}\right] / \partial T\right)$ are typically in the range $2-10 \mathrm{ppb} \mathrm{K}^{-1}$, with maximum values in urban areas having high ozone formation potential (Sillman and Samson, 1995; Baertsch-Ritter et al., 2004; Steiner et al., 2006). They tend to be lower than the observed ozone-temperature regression slopes $\left(\mathrm{d}\left[\mathrm{O}_{3}\right] / \mathrm{d} T\right)$ (Sillman and Samson, 1995). Jacob et al. (1993) find in a CTM simulation that this can be explained by the correlation of high temperature with stagnation and sunny skies, not accounted for in simple perturbation studies. Perturbation studies diagnose the partial derivative, while observed correlations diagnose the total derivative.

Water vapor has compensating effects on ozone. Increasing water vapor increases ozone loss by the reaction sequence

$\mathrm{O}_{3}+h v \rightarrow \mathrm{O}_{2}+\mathrm{O}\left({ }^{1} D\right)$

$\mathrm{O}\left({ }^{1} D\right)+\mathrm{H}_{2} \mathrm{O} \rightarrow 2 \mathrm{OH}$

where (R2) competes with reaction of the excited oxygen atom $\mathrm{O}\left({ }^{1} D\right)$ with $\mathrm{N}_{2}$ or $\mathrm{O}_{2}$, stabilizing $\mathrm{O}\left({ }^{1} D\right)$ to the ground-state atom $\mathrm{O}\left({ }^{3} P\right)$ which eventually reacts with $\mathrm{O}_{2}$ to return ozone. Because of (R2), models find that background tropospheric ozone decreases with increasing water vapor (Johnson et al., 1999). Under polluted conditions the effect is more complicated, because the $\mathrm{OH}$ radicals produced by (R2) react with VOCs and CO to produce ozone, while also converting $\mathrm{NO}_{2}$ to nitric acid to suppress ozone formation. Model perturbation studies thus find that the sensitivity of ozone to water vapor is weak and of variable sign under polluted conditions, reflecting these compensating effects (Aw and Kleeman, 2003; Baertsch-Ritter et al., 2004; Dawson et al., 2007a). Some of the correlation of ozone with relative humidity seen in the observations, as in Camalier et al.(2007) could reflect a joint association in polluted air masses rather than a cause-and-effect relationship. An additional effect under very dry conditions is drought stress on vegetation, which can suppress stomatal uptake of ozone and hence dry deposition; this effect is generally not included in models but appears to have been a significant factor contributing to the high ozone over Europe in the summer of 2003 (Vautard et al., 2005; Solberg et al., 2008).

Increasing solar radiation in model perturbation studies causes an increase of ozone, but the effect is weak (Sillman and Samson, 1995; Dawson et al., 2007a). This reflects similar complexities as in the case of increased water vapor, i.e., the increased UV flux stimulates both ozone production and loss. The observed correlation of ozone with solar radiation seen in some studies such as Ordonez et al. (2005) could reflect in part the association of clear sky with high temperatures.
Simple investigation of the sensitivity of ozone to ventilation has been conducted in models by perturbing wind speeds or mixing depths. Weaker wind speeds in polluted regions cause ozone to increase, as would be expected simply from a longer reaction time and increased aerodynamic resistance to dry deposition (Baertsch-Ritter et al., 2004; Sanchez-Ccoyllo et al., 2006; Dawson et al., 2007a). Mixing depths have a more complicated effect, reflecting the ambiguity seen in the observational analyses (Section 3). Ozone concentrations in the lower free troposphere at northern mid-latitudes are typically about $60 \mathrm{ppb}$ (Logan, 1999), so that increasing mixing depth entrains relatively high-ozone air; in addition, diluting $\mathrm{NO}_{x}$ in a deeper mixed layer increases its ozone production efficiency (Liu et al., 1987; Kleeman, 2007). The model sensitivity study by Dawson et al. (2007a) for the eastern U.S. finds a positive dependence of ozone on mixing depth where surface ozone is low and a negative dependence where it is high, consistent with the above arguments. Sanchez-Ccoyllo et al. (2006) find a decrease in simulated ozone for the Sao Paulo metropolitan area as the mixing depth increases, reflecting the low ozone background there. Aw and Kleeman (2003) find little sensitivity of ozone to mixing depth in model simulations of the Los Angeles Basin, which may reflect ozone enrichment of the lower free troposphere due to diurnal pollutant venting. Additional Los Angeles Basin simulations by Kleeman (2007) show both positive and negative ozone responses to increases in mixing depth.

\subsection{Particulate matter}

Model perturbation studies find that the effect of temperature on PM depends on the PM component. Sulfate concentrations increase with temperature (Aw and Kleeman, 2003; Dawson et al., 2007b; Kleeman, 2007), due to faster $\mathrm{SO}_{2}$ oxidation (higher rate constants and higher oxidant concentrations). In contrast, nitrate and organic semi-volatile components shift from the particle phase to the gas phase with increasing temperature (Sheehan and Bowman, 2001; Tsigaridis and Kanakidou, 2007). Model sensitivity studies indicate large decreases of nitrate PM with increasing temperature, dominating the overall effect on PM concentrations in regions where nitrate is a relatively large component (Dawson et al., 2007b; Kleeman, 2007). Aw and Kleeman (2003) and Dawson et al. (2007b) find mean nitrate PM decreases of 7 and $15 \% \mathrm{~K}^{-1}$ in Los Angeles and the eastern U.S. respectively. Both studies find much weaker sensitivities of organic PM to temperature, reflecting the weaker temperature dependences of the gas-particle equilibrium constants. Overall, Dawson et al. (2007b) find mean negative dependences of total $\mathrm{PM}_{2.5}$ in the eastern U.S. of $2.9 \% \mathrm{~K}^{-1}$ in January and $0.23 \% \mathrm{~K}^{-1}$ in July, the larger effect in winter reflecting the greater abundance of nitrate. Some sulfate-rich regions in their simulation exhibit a positive dependence in summer.

PM concentrations decrease with increasing precipitation as wet deposition provides the main PM sink. The critical variable is precipitation frequency rather than precipitation rate, since scavenging within a precipitating column is highly efficient (Balkanski et al., 1993). Dawson et al. (2007b) perturbed precipitation areas and rates in their CTM and find a high PM sensitivity in summer, when events tend to be convective and small in scale, vs. a low sensitivity in winter when synoptic-scale storms dominate. This is consistent with precipitation frequency being the dominant factor.

Changes in ventilation (wind speed, mixing depth) have stronger effects on PM than on ozone because of the lower PM background concentrations. PM concentrations typically decrease by an order of magnitude between polluted regions and the diluting background air, whereas for ozone the decrease is typically less than a factor of 2 and concentrations may actually increase with altitude. Dawson et al. (2007b) and Kleeman (2007) find that increasing ventilation rates in their models has a simple diluting 


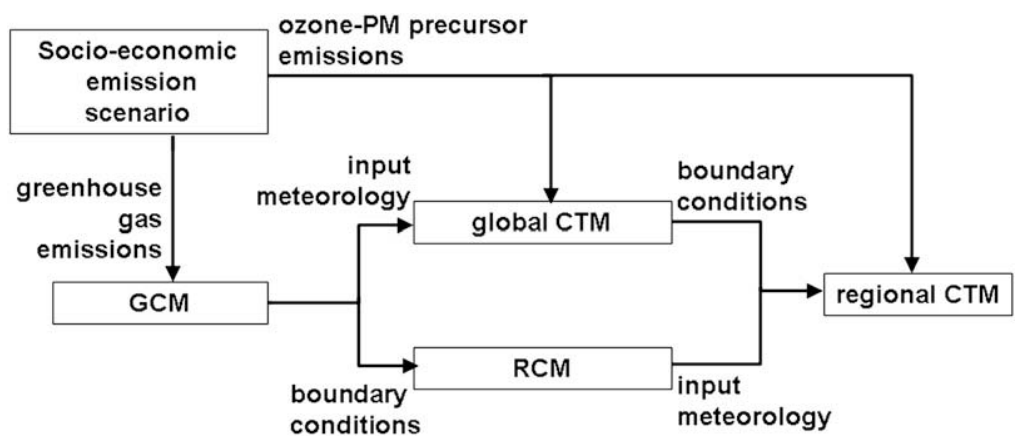

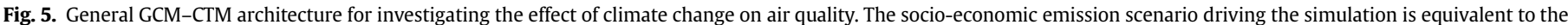

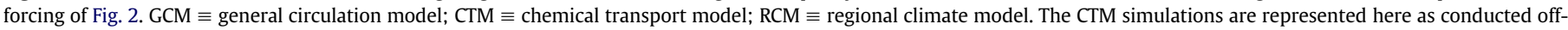
line from the parent meteorological model (GCM or RCM), but they can also be conducted on-line (see Section 5.1).

effect on PM. Pye et al. (in press) point out that increasing mixing depth in the future climate is generally associated with a decrease in precipitation, representing a compensating effect.

Changes in humidity and cloudiness also affect PM. Increasing relative humidity increases the PM water content and hence the uptake of semi-volatile components, mainly nitrate and also possibly organics. Dawson et al. (2007b) find in their model perturbation studies a large sensitivity of nitrate PM to humidity, but little sensitivity of other PM components. They find little sensitivity to changing cloud cover or liquid water content, despite the importance of clouds for sulfate production by aqueous-phase oxidation of $\mathrm{SO}_{2}$. A likely explanation is that cloud frequency, i.e., the frequency for processing of air through cloud, is the critical variable since aqueous-phase $\mathrm{SO}_{2}$ oxidation by $\mathrm{H}_{2} \mathrm{O}_{2}$ in cloud takes place on a time scale of minutes. This processing frequency and more generally the simulation of aqueous-phase sulfate formation in clouds is difficult to parameterize adequately in either mesoscale or global models (Koch et al., 2003).

\section{GCM-CTM studies}

\subsection{General approach}

Empirical correlations and model perturbation studies as described in the previous sections cannot capture the complex coupling between meteorological variables involved in climate change nor the parallel change in anthropogenic emissions. A CTM driven by future-climate GCM fields is required. Fig. 5 shows the general architecture of the GCM-CTM approach. A scenario of future greenhouse gas emissions drives a GCM simulation of global climate change. The GCM provides input to a CTM that simulates atmospheric composition on a global scale. Changes in the global anthropogenic emissions of ozone and PM precursors consistent with the greenhouse scenario may also be input to the CTM, or not if one wishes to isolate the effect of climate change. The GCM can provide boundary conditions to a regional climate model (RCM) for finer-scale resolution of climate change over the region of interest. The air quality simulation is then done with a regional CTM using meteorological input from the RCM, chemical boundary conditions from the global CTM, and (if one wishes) future pollutant emissions. The CTM simulation can be integrated on-line within the GCM/RCM (Giorgi and Meleux, 2007), but is more often conducted off-line using archived GCM/RCM meteorological fields (e.g., Liang et al., 2006). The off-line approach has more computational flexibility but it requires a separate transport code to replicate that of the GCM/ RCM as well as customized archival of GCM/RCM meteorological data affecting the air quality simulation (such as convective mass fluxes, boundary layer turbulence, vertical distribution of precipitation). We refer here to GCM-CTMs as chemical simulations driven by GCM meteorology, whether the CTM is on-line or off-line.

The GCM-CTM approach offers a general and flexible framework for investigating the effect of climate change on air quality, but it is computationally expensive. Consider an investigation of 2000-2050 climate change. This requires a continuous GCM simulation for the 50-year period with time-dependent radiative forcing of climate. The reference point for the air quality simulation must be the GCM year 2000, not the observed meteorological year 2000; the two are different since the GCM is not forced by observations and thus can only simulate a hypothetical year consistent with 2000 climate. Because of natural interannual variability in the GCM (a consequence of chaos in the equation of motion), one cannot simply compare CTM simulations for GCM year 2050 vs. GCM year 2000 to diagnose the effect of climate change. It could be for example that these particular GCM years are anomalously cool or warm. In the same way that multiple years of observations are needed to generate air quality statistics for the present-day climate, it is necessary to conduct several years of CTM simulations centered around the target GCM years (here 2000 and 2050) in order to separate the effect of climate change from interannual variability. Downscaling to the regional scale compounds the computational challenge. To reduce cost and complexity, GCM-CTM studies in the literature often omit some of the components in Fig. 5. Some omit the regional components and diagnose change in air quality from the global CTM simulation (with spatial resolution of a few hundred $\mathrm{km}$ ). Others omit the global CTM component and hence ignore climate-driven changes in background concentrations.

\subsection{Ozone}

A large number of global GCM-CTM studies have investigated the effect of 21st-century climate change on the global tropospheric ozone budget and the surface ozone background; they are reviewed by Wu et al. (2008b) and are not discussed in detail here since our focus is on regional ozone pollution. The most important climate variables affecting tropospheric ozone on a global scale are stratosphere-troposphere exchange, lightning $\mathrm{NO}_{x}$, and water vapor. These three variables are all expected to increase in the future climate; the first two cause an increase in ozone and the third a decrease. Different models thus project changes in the global tropospheric ozone burden over the 21st century ranging from $-5 \%$ to $+12 \%$ (Wu et al., 2008b). Despite this disagreement in sign, the models agree that climate change will decrease the ozone background in the lower troposphere where the water vapor effect is dominant (stratosphere-troposphere exchange and lightning are more important in the upper troposphere). An ensemble analysis of 10 global GCM-CTMs by Dentener et al. (2006) indicates a decrease of annual mean surface ozone in the northern hemisphere by 
Table 2

GCM-CTM studies of the effect of climate change on ozone air quality. ${ }^{\mathrm{a}}$

\begin{tabular}{|c|c|c|c|c|c|}
\hline Reference & Domain $^{b}$ & Scenario $^{c}$ & Time horizon $^{\mathrm{d}}$ & $\begin{array}{l}\text { Metric } \\
\text { reported }\end{array}$ & Surface ozone change (ppb) \\
\hline Hogrefe et al. (2004) & Eastern U.S. & A2 & 2080 vs. 1990 & $\mathrm{JJA} \mathrm{MDA8}^{\mathrm{f}}$ & $\begin{array}{l}50 \text { eastern U.S. cities: }+4.4(2050)^{g} \\
\text { Eastern U.S.: }+2.7(2020),+4.2(2050),+5.0(2080)\end{array}$ \\
\hline Liao et al. (2006) & Global & $\mathrm{A} 2$ & 2100 vs. 2000 & July mean & $\begin{array}{l}\text { Northeastern U.S.: }+4-8 \\
\text { Central Europe: }+2-6\end{array}$ \\
\hline Murazaki and Hess (2006) & Global & A1 & 2090 vs. 1990 & JJA MDA8 & $\begin{array}{l}\text { Eastern U.S.: }+2-5 \\
\text { Western U.S.: insignificant }\end{array}$ \\
\hline Racherla and Adams (2006) & Global & $\mathrm{A} 2$ & 2050 vs. 1990 & Summer mean & Eastern U.S.: +1-5 \\
\hline Kunkel et al. (2007) & $\begin{array}{l}\text { Global/ } \\
\text { northeastern U.S. }\end{array}$ & A1FI, B1 & 2090 vs. 1990 & JJA MDA8 & Northeastern U.S.: +10-25\% (A1FI), +0-10\% (B1) \\
\hline Tagaris et al. (2007) & U.S. & A1B & 2050 vs. 1990 & JJA MDA8 & $\begin{array}{l}\text { Midwest U.S.: }-2.5 \% \\
\text { Northeastern U.S.: }+2.8 \%\end{array}$ \\
\hline Jacobson (2008) & Global/urban & & $\begin{array}{l}\text { Present vs. } \\
\text { preindustrial } \mathrm{CO}_{2}\end{array}$ & Jul-Nov means & $\begin{array}{l}\text { Mean U.S.: }+0.12^{\mathrm{h}} \\
\text { Los Angeles: }+5\end{array}$ \\
\hline Lin et al. (2008a) & Global & A1FI, B1 & 2090 vs. 1990 & JJA MDA8 & $\begin{array}{l}\text { U.S.: +3-12 (A1FI), +3-6 (B1) } \\
\text { Eastern China: +3-12 (A1FI), +1-5 (B1) }\end{array}$ \\
\hline Nolte et al. (2008) & Global/U.S. & A1B & 2050 vs. 2000 & $\mathrm{JJA} \mathrm{MDA}^{\mathrm{i}}$ & $\begin{array}{l}\text { Texas, eastern U.S.: }+1-8 \\
\text { Midwest, northwestern U.S.: }-1-3\end{array}$ \\
\hline Wu et al. (2008a) & Global & A1B & 2050 vs. 2000 & JJA MDA8 & $\begin{array}{l}\text { Midwest, northeastern U.S.: }+2-5 \\
\text { Southeastern U.S.: insignificant }\end{array}$ \\
\hline Avise et al. (submitted for publication) & U.S. & A2 & 2050 vs. 2000 & July MDA8 & $\begin{array}{l}\text { Northeastern U.S.: }+4 \\
\text { Southeastern U.S.: }-6\end{array}$ \\
\hline Langner et al. (2005) & Europe & IS92a $^{\mathrm{j}}$ & 2060 vs. 2000 & Apr-Sept MDA ${ }^{\mathrm{k}}$ & $\begin{array}{l}\text { South-central Europe: }+0-12 \% \\
\text { Scandinavia: }-0-4 \%\end{array}$ \\
\hline Forkel and Knoche $(2006,2007)$ & Europe & IS92a & 2030 vs. 1990 & JJA MDA & $\begin{array}{l}\text { N. Italy: }+10 \\
\text { S. Germany, E. France: }+5-7\end{array}$ \\
\hline Meleux et al. (2007) & Europe & A2, B2 & 2085 vs. 1975 & JJA MDA & West-central Europe: $+10-18(\mathrm{~A} 2),+2-8$ (B2) \\
\hline $\begin{array}{l}\text { a Effect of climate change only, holdi } \\
\text { b Slashes indicate nesting of global a } \\
\text { c Socio-economic scenario for } 21 \mathrm{st}-\mathrm{c} \\
\text { growth and efficient introduction of nev } \\
\text { and efficient technologies), B2 (focus o } \\
\text { technological emphasis. } \\
\text { d Climate change is computed from a } \\
\text { simulate several years around the targ } \\
\text { e Selected results; more information } \\
\text { f June-July-August maximum daily } \\
\text { g Result presented in Bell et al. (2007 } \\
\text { h +0.72 ppbv for areas with surface } \\
\text { i Results for September-October ind } \\
\text { j Older scenario from the IPCC 2nd } A \\
\text { k Maximum daily ozone, averaging ti }\end{array}$ & $\begin{array}{l}\text { anthropogenic emi } \\
\text { regional CTMs. } \\
\text { ury greenhouse gas } \\
\text { chnologies), A2 (ve } \\
\text { ustainability, intern } \\
\text { nsient GCM simula } \\
\text { ear to resolve inter } \\
\text { given in the origina } \\
\text { average. } \\
\text { ne }>35 \text { ppbv. } \\
\text { in general larger } \\
\text { ssment Report, wit } \\
\text { not specified. }\end{array}$ & $\begin{array}{l}\text { missions fro } \\
\text { heterogene } \\
\text { diate econo } \\
\text { n over the } \\
\text { nual variab } \\
\text { eference. Sc }\end{array}$ & $\begin{array}{l}\text { the IPCC Special Re } \\
\text { is world with sluggis } \\
\text { c development). Th } \\
\text { licated time horizon } \\
\text { y. }\end{array}$ & $\begin{array}{l}\text { t on Emission Sc } \\
\text { conomic growth) } \\
\text { scenario furthe } \\
\text { incept for Liao et a } \\
\text { inceases or dec }\end{array}$ & $\begin{array}{l}\text { arios (Nakicenovic et al., 2000): A1 (rapid economic } \\
1 \text { (convergent world with rapid introduction of clean } \\
\text { istinguishes three sub-scenarios (A1FI, A1T, A1B) by } \\
\text { 2006), who used equilibrium climates). Most studies } \\
\text { ses. }\end{array}$ \\
\hline
\end{tabular}

$0.8 \pm 0.7 \mathrm{ppb}$ for $2000-2030$ climate change, with the standard deviation describing the spread between models.

Table 2 lists the GCM-CTM studies in the literature that have examined the effect of climate change on regional ozone pollution. Almost all have targeted North America or Europe. The only targeted study of eastern Asia is that of Lin et al. (2008a). The results in Table 2 indicate that polluted regions at northern mid-latitudes will experience higher surface ozone as a result of 21st-century climate change, despite the decrease in the surface ozone background. The projected increases are typically in the $1-10 \mathrm{ppb}$ range and are found to be driven primarily by temperature, consistent with the correlative and model sensitivity analyses discussed in Sections 3 and 4. Decreases are found only in relatively clean areas where ozone is largely determined by its background (Lin et al., 2008a; Nolte et al., 2008; Wu et al., 2008b), and in areas projected by the specific GCM/RCM to experience increased cloudiness and little warming: Scandinavia in Langner et al. (2005), the Midwest U.S. in Tagaris et al. (2007) and Nolte et al. (2008) (who used the same driving meteorological fields), the southeastern U.S. in Avise et al. (submitted for publication). Nolte et al. (2008) find larger increases (3-8 ppb) over the central U.S. in September-October than in summer, which might reflect a seasonal shift to NMVOC-limited conditions more sensitive to isoprene emission (Jacob et al., 1995).

A general finding among models is that the ozone increase from climate change is largest in urban areas where present-day ozone is already high (Bell et al., 2007; Jacobson, 2008; Nolte et al., 2008). This is consistent with the model perturbation studies reviewed in
Section 4 and reflects the high ozone production potential of urban air. Most models also find that the sensitivity of ozone to climate change is highest during pollution episodes (Hogrefe et al., 2004; Tagaris et al., 2007; Wu et al., 2008a), although some studies do not find such an effect (Murazaki and Hess, 2006; Lin et al., 2008a). For pollution episodes (i.e., at the high end of the ozone probability distribution), Wu et al. (2008a) and Hogrefe et al. (2004) find increases of up to $10 \mathrm{ppb}$ by 2050 and up to $17 \mathrm{ppb}$ by 2080 respectively. Wu et al. (2008a) argue that the higher sensitivity during episodes reflects a similar trend in temperature, i.e., the temperature rise during heat waves is larger than that of mean temperature.

Significant ozone increases in the northeastern U.S. are found in all the models of Table 2 . This likely reflects the strong sensitivity of ozone in that region to temperature and to the frequency of frontal passages, for which climate projections are consistent across GCMs. Significant increases are also found in all models for southern and central Europe, where future climate projections consistently show large warming and decreased cloudiness in summer (Christensen et al., 2007). Other regions show less consistency between models. Racherla and Adams (2006) and Tao et al. (2007) find large ozone increases in the southeastern U.S. while Wu et al. (2008a) find little effect there and Avise et al. (submitted for publication) find a large decrease. Wu et al. (2008a) find a large ozone increase in the Midwest due to increased stagnation while Tagaris et al. (2007) and Nolte et al. (2008) find a decrease there due to increased cloudiness. Murazaki and Hess (2006) find no significant increase in the 
Table 3

GCM-CTM studies of the effect of climate change on PM air quality. ${ }^{\mathrm{a}}$

\begin{tabular}{|c|c|c|c|c|c|}
\hline Reference & Model & Scenario $^{\mathrm{b}}$ & Time horizon $^{c}$ & Metric reported & $\begin{array}{l}\text { Surface PM } \\
\text { change }\left(\mu \mathrm{g} \mathrm{m}^{-3}\right)^{\mathrm{d}}\end{array}$ \\
\hline $\begin{array}{l}\text { Liao et al. (2006); Racherla } \\
\text { and Adams (2006) }\end{array}$ & Global & A2 & 2100 vs. 2000 & Annual mean & $\begin{array}{l}\text { Central Europe: }+1 \text { (sulfate), } \\
+0.5-1 \text { (carbonaceous) } \\
\text { Eastern U.S.: }+1 \text { (sulfate) }\end{array}$ \\
\hline Tagaris et al. (2007) & U.S. & A1B & 2050 vs. 2000 & Annual mean & U.S.: $-10 \%\left(\mathrm{PM}_{2.5}\right)$ \\
\hline Unger et al. (2006) & Global & B1 & 2030 vs. 1990 & Annual mean & $\begin{array}{l}\text { Southern Europe: } \\
+0.1-1 \text { (sulfate) }\end{array}$ \\
\hline Heald et al. (2008) & Global & A1B & 2100 vs. 2000 & Annual mean & $\begin{array}{l}\text { Eastern U.S.: }+0.5 \\
\text { (secondary OC) }\end{array}$ \\
\hline Jacobson (2008) & Global/urban & & $\begin{array}{l}\text { Present vs. } \\
\text { preindustrial } \mathrm{CO}_{2}\end{array}$ & Jul-Nov mean & U.S.: $+0.065\left(\mathrm{PM}_{2.5}\right)$ \\
\hline $\begin{array}{l}\text { Spracklen et al. } \\
\text { (submitted for publication) }\end{array}$ & Global & A1B & 2050 vs. 2000 & JJA mean & $\begin{array}{l}\text { Western U.S.: }+0.5 \\
\text { (carbonaceous) }^{\mathrm{e}}\end{array}$ \\
\hline Pye et al. (in press) & Global & A1B & 2050 vs. 2000 & Annual mean & $\begin{array}{l}\text { U.S.: }-0.3 \text { to }+0.3 \text { (sulfate), } \\
-0.2 \text { to } 0 \text { (nitrate) }\end{array}$ \\
\hline $\begin{array}{l}\text { Avise et al. } \\
\text { (submitted for publication) }\end{array}$ & U.S. & A2 & 2050 vs. 2000 & July mean & U.S.: $-1\left(\mathrm{PM}_{2.5}\right)$ \\
\hline
\end{tabular}

a Effect of climate change only, holding anthropogenic emissions of PM and precursors constant.

b See footnote in Table 2.

c See footnote in Table 2.

d Selected results; more information is given in the original reference. Some results are given as \% changes.

e Climate-driven increase in wildfires accounts for $70 \%$ of this increase.

western U.S. due to the effect of the reduced ozone background, but Tao et al. (2007) find large increases there.

Differences in air pollution meteorology between GCMs/RCMs are a major cause of the above discrepancies (Kunkel et al., 2007). Differences between CTMs in the parameterizations of natural emissions, chemistry, and deposition also play a role. Wu et al. (2008a) point out that model differences in isoprene oxidation mechanisms have significant implications for sensitivity to climate change in regions where $\mathrm{NO}_{x}$ is relatively low and isoprene is high, such as the southeastern U.S. Oxidation of isoprene by $\mathrm{OH}$ produces organic peroxy radicals $\mathrm{RO}_{2}$, which react with $\mathrm{NO}$ by two branches:

$\mathrm{RO}_{2}+\mathrm{NO} \rightarrow \mathrm{RO}+\mathrm{NO}_{2}$

$\mathrm{RO}_{2}+\mathrm{NO}+\mathrm{M} \rightarrow \mathrm{RONO}_{2}+\mathrm{M}$

(R3a) goes on to produce ozone by $\mathrm{NO}_{2}$ photolysis, while (R3b) produces isoprene nitrates and can be a major sink for $\mathrm{NO}_{x}$ (Liang et al., 1998). Isoprene nitrate chemistry is highly uncertain, as reviewed by Horowitz et al. (2007). Isoprene nitrate yields R3b/ (R3a $+\mathrm{R} 3 \mathrm{~b}$ ) range in the literature from 4 to $15 \%$, and the fate of these nitrates (in particular whether they recycle $\mathrm{NO}_{x}$ or represent terminal sinks) remains largely unknown (Giacopelli et al., 2005). A recent chamber study by Paulot et al. (2008) finds a 11\% yield of isoprene nitrates with $50 \%$ regeneration of $\mathrm{NO}_{x}$ upon subsequent oxidation. There may also be substantial production of isoprene nitrates from oxidation of isoprene by the nitrate radical but this is even less understood (Horowitz et al., 2007). Wu et al. (2008a) find that their assumed isoprene nitrate yield of $12 \%$, with no $\mathrm{NO}_{x}$ recycling, is responsible for their lack of sensitivity of ozone to climate change in the southeastern U.S. Racherla and Adams (2006) did not include isoprene nitrate formation in their model and find by contrast a large ozone sensitivity to climate change in that region.

Another major factor of uncertainty is the sensitivity of isoprene emission to climate change. All the models in Table 2 use similar parameterizations for isoprene emission in which the main dependence is on temperature, with roughly a doubling of emissions per $4 \mathrm{~K}$ temperature increase (Guenther et al., 2006). But it is not clear that this standard model dependence, based on short- term observations for the present climate, is relevant to the much longer time scales involved in climate change. In addition, there is evidence that increasing $\mathrm{CO}_{2}$ causes plants to decrease isoprene emission (Centritto et al., 2004; Arneth et al., 2007; Monson et al., 2007), and this is not accounted for in the models of Table 2 (except for Lin et al. (2008a), who assume a very weak dependence). A study by Heald et al. (in press) of 2000-2100 change of isoprene emission for the $\mathrm{A} 1 \mathrm{~B}$ climate (717 ppm $\mathrm{CO}_{2}$ in 2100) finds a global $37 \%$ increase in emission when only temperature is taken into effect, a $8 \%$ decrease when both changes in temperature and $\mathrm{CO}_{2}$ are considered, and a doubling when changes in net primary productivity (NPP) and land cover are also considered. The response of land cover to climate change is very uncertain, and forest dieback in regions subjected to drier climates would cause isoprene emission to decrease (Sanderson et al., 2003).

\subsection{Particulate matter}

Table 3 lists the GCM-CTM studies that have examined the impact of 21st-century climate change on surface PM concentrations in polluted regions. Projected changes are in the range $\pm 0.1-$ $1 \mu \mathrm{g} \mathrm{m}^{-3}$. This represents a potentially significant effect but there is little consistency between studies, including in the sign of the effect. Racherla and Adams (2006), Tagaris et al. (2007), and Avise et al. (submitted for publication) emphasize the importance of changing precipitation in modulating the PM sink. Tagaris et al. (2007) find a $10 \%$ decrease in $\mathrm{PM}_{2.5}$ throughout the U.S. due to increased precipitation in the future climate. Racherla and Adams (2006) find a global decrease in $\mathrm{PM}_{2.5}$, as would be expected from the global precipitation increase, but a regional increase in the eastern U.S. due to lower precipitation there. Differences between $\mathrm{GCM} / \mathrm{RCMs}$ in the regional precipitation response to climate change are a major cause of discrepancy in the PM response (Racherla and Adams, 2006; Pye et al., in press). From the IPCC ensemble of models (Fig. 3), one may expect changes in precipitation to drive PM increases in southern North America and southern Europe, but decreases in most other continental regions of northern midlatitudes.

Factors other than precipitation are also important in driving the sensitivity of PM to climate change. Liao et al. (2006), Unger et al. (2006), and Pye et al. (in press) point out that higher water vapor in the future climate leads to higher concentrations of $\mathrm{H}_{2} \mathrm{O}_{2}$, the 
principal $\mathrm{SO}_{2}$ oxidant, thus increasing sulfate concentrations. Liao et al. (2006) find that increased stagnation in the future climate causes PM to increase in polluted regions. A study of secondary organic PM by Heald et al. (2008) finds a positive response to rising temperature in continental regions due to increasing biogenic NMVOC emissions.

Increasing frequency of wildfires from droughts in the future climate could be yet another important factor driving PM increases. The anomalously hot summer 2003 in Europe was associated with record wildfires that significantly degraded air quality for both PM and ozone (Vautard et al., 2007; Solberg et al., 2008). The GCMCTM study of Spracklen et al. (submitted for publication) including projection of climate-driven increase in wildfires finds a $0.5 \mu \mathrm{g} \mathrm{m}^{-3}$ increase in carbonaceous PM in the western U.S. in summer.

\section{Effect of climate change on mercury}

The effect of climate change on mercury cycling has received no attention to date but is a potentially important issue. Increased volatilization of mercury from ocean and land reservoirs as a result of climate change would transfer mercury between ecosystems via atmospheric transport, re-depositing it in a more mobile and presumably more toxic form. Volatilization of mercury from the ocean is directly affected by warming (lower solubility of elemental mercury) and would also be affected by changes in ocean biology and circulation (Strode et al., 2007; Sunderland and Mason, 2007). Increased volatilization of soil mercury could potentially be of considerable importance, as the amount of mercury stocked in soil $\left(1.2 \times 10^{6} \mathrm{Mg}\right)$ dwarfs that in the atmosphere $\left(6 \times 10^{3} \mathrm{Mg}\right)$ and in the ocean $\left(4 \times 10^{4} \mathrm{Mg}\right)$ (Selin et al., 2008). Soil mercury is mainly bound to organic matter (Ravichandran, 2004). Future warming at boreal latitudes could release large amounts of soil organic matter to the atmosphere as $\mathrm{CO}_{2}$, both through increased respiration (Raich and Schlesinger, 1992) and increased fires (Spracklen et al., submitted for publication). It is not known whether organic-bound mercury is emitted or retained in the soil when the carbon is respired. Boreal peatland fires may have very high mercury emissions from burning of the peat (Turetsky et al., 2006).

\section{Implications for air quality management}

There is consistent evidence from models and observations that 21st-century climate change will worsen ozone pollution. The effect on PM is uncertain but potentially significant. When assuming business-as-usual future scenarios without significant emission reductions beyond current regulations, models find that the combined effects of emissions changes and climate change in the U.S. will result in increased ozone pollution (Hogrefe et al., 2004; Steiner et al., 2006; Tao et al., 2007; Chen et al., submitted for publication). Simulations that assume emission reductions far beyond the full implementation of current regulations indicate that climate change will partly offset the benefit of the emissions reductions (Tao et al., 2007; Tagaris et al., 2007; Nolte et al., 2008). Wu et al. (2008a) refer to this 'climate penalty' as the need for stronger emission controls to achieve a given air quality standard. In an example for the U.S. Midwest, they find that an air quality objective attainable with a $40 \% \mathrm{NO}_{x}$ emission reduction for the present climate would require a $50 \% \mathrm{NO}_{x}$ reduction in the 2050 climate. They find that this climate penalty decreases as anthropogenic $\mathrm{NO}_{x}$ emissions decrease, thus providing additional return on $\mathrm{NO}_{x}$ emission controls.

The work of Leibensperger et al. (submitted for publication) using 1980-2006 ozone data for the northeastern U.S. (Fig. 1) highlights the potential importance of climate change for air quality managers. By using the observed interannual correlation between cyclone frequency and exceedances of the ozone air quality standard, Leibensperger et al. (submitted for publication) conclude that the ozone air quality standard would have been met in the northeastern U.S. by 2001 were it not for the decreasing trend in cyclone frequency indicated by the NCEP/NCAR Reanalysis. There is uncertainty as to the actual long-term cyclone trend in the 19802006 record, but the point here is that climate change can significantly affect the accountability of air quality management decisions on a decadal time scale.

An important issue is whether climate change could affect the dependence of ozone on $\mathrm{NO}_{x}$ and NMVOC emissions in a way that would compromise the effectiveness of current emission control strategies. Liao et al. (2007) examined this issue for the U.S. with the model of Tagaris et al. (2007) and found no significant effect, implying that emission control strategies designed for the present climate should still be successful in the future climate. Model simulations by Baertsch-Ritter et al. (2004) for the Milan urban plume show increased ozone sensitivity to NMVOCs as temperature increases, due to the reduced thermal stability of PAN and hence higher concentrations of $\mathrm{NO}_{x}$. By contrast, model simulations by Cardelino and Chameides (1990) for the Atlanta urban plume show increased ozone sensitivity to $\mathrm{NO}_{x}$ as temperature increases, due to increasing isoprene emission and supply of $\mathrm{HO}_{x}$ radicals. The opposite responses of the Milan and Atlanta plumes likely reflect regional differences in biogenic NMVOC emissions, but the point from both studies is that sensitivities of ozone to $\mathrm{NO}_{x}$ and NMVOC emissions could be affected by climate change.

Pollutant emissions are also expected to respond to climate change. Higher temperatures increase the demand for air conditioning in summer when ozone and PM concentrations are highest. Evaporative emissions of anthropogenic NMVOCs also increase, although the effect determined for mobile sources is relatively weak, in the range $1.3-5 \% \mathrm{~K}^{-1}$ (Cardelino and Chameides, 1990; Rubin et al., 2006).

The ozone background is likely to become an increasingly important issue for air quality managers as air quality standards become tighter. This background is likely to increase in the future because of global increase in methane and $\mathrm{NO}_{x}$ emissions (Fiore et al., 2002). Climate change may provide some relief, at least in summer. Wu et al. (2008b) find that the U.S. policy-relevantbackground (PRB), defined by the U.S. Environmental Protection Agency (EPA) as the surface ozone concentration in the absence of North American anthropogenic emissions, will decrease by up to $2 \mathrm{ppb}$ in summer as a result of 2000-2050 climate change. Lin et al. (2008b) obtain similar results. Wu et al. (2008b) project that climate change will fully offset the effect of rising global anthropogenic emissions on the PRB in the eastern U.S. in summer, though there will still be a $2-5 \mathrm{ppb}$ increase in the PRB in the west. Seasons outside summer will experience less benefit from climate change in terms of decreasing the ozone background, while experiencing stronger intercontinental transport of pollution (Fiore et al., 2002).

Finally, as the world moves forward to develop energy and transportation policies directed at mitigating climate change, it will be important to factor into these policies the co- or dis-benefits for regional air pollution. Energy policy offers an opportunity to dramatically improve air quality through transition to nonpolluting energy sources. By contrast, a switch to biofuels would not necessarily benefit air quality and could possibly be detrimental (Jacobson, 2007).

\section{Conclusions}

We reviewed current knowledge of the effect of climate change on air quality with focus on 21st-century projections for ozone and particulate matter (PM). We examined results from various approaches to the problem including observed correlations of ozone and PM with meteorological variables, perturbation studies 
using regional chemical transport models (CTMs), and futureclimate simulations with general circulation models (GCMs) coupled to CTMs. We discussed the implications for air quality management and pointed out the possibly large but unexplored effect of climate change on the atmospheric cycling of mercury.

There is consensus among GCMs that 21st-century climate change will increase the frequency of stagnation episodes over northern mid-latitudes continents. This increase in stagnation reflects the weakening of the general circulation and a northward shift of the mid-latitude cyclone tracks, decreasing the frequency of cold fronts that are the principal ventilation mechanism for eastern North America, Europe, and East Asia. General degradation of air quality is therefore expected if anthropogenic emissions remain constant.

Observations of high-ozone events in different polluted regions of the world show a consistently strong correlation with temperature. This correlation can be reproduced by models where it reflects in part the thermal stability of PAN, in part the biogenic emission of isoprene, and in part the joint association of high ozone and temperature with stagnation. Considering that rising temperature is a robust projection of 21 st-century climate change, the ozone-temperature correlation offers a simple observational argument that climate change will be detrimental to ozone air quality.

Coupled GCM-CTM studies for the 21st-century climate assuming constant anthropogenic emissions find indeed widespread summertime increases of surface ozone in polluted regions of North America, Europe, and Asia. Rising temperature is found to be the principal factor driving these increases. Ozone increases are of the order of 1-10 ppb depending on the time horizon, region, climate scenario, and model used. All models find that the sensitivity of ozone to climate change is particularly high in urban areas, reflecting the high potential for ozone formation. Most (but not all) models find that the sensitivity is strongest at the high end of the frequency distribution, i.e., during pollution episodes, reflecting the increased frequency and duration of stagnation events. All models find significant ozone increases in the northeastern U.S. and in south-central Europe. Other regions, such as the southeastern U.S., show large differences between models. This partly reflects differences in regional climate projections, but also the choice of isoprene chemistry mechanism including the uncertain yield and fate of isoprene nitrates.

Background ozone in air ventilating polluted regions responds to climate change very differently from regional ozone pollution. Background ozone is not correlated with temperature, and is expected instead to decrease in the future climate as a result of increasing water vapor (by contrast, regional ozone pollution is expected to be have little sensitivity to change in water vapor because of compensating effects). The beneficial effect of climate change on the ozone background may partly offset the expected global increase in the ozone background due to rising methane and Asian $\mathrm{NO}_{x}$ emissions over the coming decades. The offset is likely to be more important in summer than in other seasons.

The response of PM to climate change is more complicated than that for ozone because of the diversity of PM components, compensating effects, and general uncertainty in GCM projections of the future hydrological cycle. Observations show little useful correlation of PM with climate variables to guide inferences of the effect of climate change. Rising temperature is expected to have a mild negative effect on PM due to volatilization of semi-volatile components (nitrate, organic), partly compensated by increasing sulfate production. Increasing stagnation should cause PM to increase. Precipitation frequency, which largely determines PM loss, is expected to increase globally but to decrease in southern North America and southern Europe. PM is highly sensitive to mixing depths but there is no consensus among models on how these will respond to climate change.
GCM-CTM studies of the sensitivity of surface PM to 21stcentury climate change find annual mean effects of the order of $\pm 0.1-1 \mu \mathrm{g} \mathrm{m}^{-3}$ for North America and Europe, with no consensus between studies as to the sign of the effect. Increases in wildfires driven by climate change could significantly increase PM concentrations beyond the direct effect of changes in meteorological variables.

It emerges from the state of current knowledge that climate change represents a significant penalty for air quality managers toward the achievement of ozone air quality goals. The effect on PM air quality could also be significant but is far more uncertain. Wildfire management for PM abatement will likely become an increasing consideration. The climate penalty for ozone air quality implies the need for more stringent emission controls to attain a given air quality objective. It does not affect in a major way the type of emission control strategies needed, although attention is needed to possible local shifts between $\mathrm{NO}_{x}$-limited and NMVOClimited conditions for ozone production. Decreasing ozone background in the future climate due to higher water vapor will partly mitigate the climate penalty and increase the return from $\mathrm{NO}_{x}$ emission controls.

\section{Future directions}

Consideration of the effect of climate change on air quality in the design of air quality and climate policy will require increased confidence in model simulations of this effect. A first measure of confidence is consensus. Consensus among models can be assessed by analyzing statistics of results from a number of GCM-CTMs applied to identical scenarios of greenhouse gas and pollutant emissions. Such assessments using model ensembles are routinely done by the IPCC for physical climate variables (cf. Fig. 3). A first step towards applying this approach to air quality was taken by Weaver et al. (submitted for publication), who compared the effect of 20002050 climate change on U.S. ozone for six of the models in Table 2. They highlighted regions of agreement and disagreement, and discussed the factors contributing to differences between models.

Consensus among models can be misleading, however, as some inadequacies and errors are common to all models. One general issue is the coupling between global and regional scales. Proper representation of the global scale is fundamental to the climate simulation, and is also important for the air quality simulation to describe changes in background and in intercontinental transport of pollution. However, the $\sim 100 \mathrm{~km}$ resolution typical of global models is inadequate to resolve small-scale meteorological features and chemical non-linearities relevant to air quality. Dynamical downscaling using RCMs is necessary but maintaining consistency between GCM and RCM physics is a challenge. All coupled globalregional GCM-CTM studies so far have used one-way nesting, where the global models provide physical and chemical boundary conditions to the regional models (Fig. 5). This poses continuity problems at the boundaries, as the regional model does not influence the global model. Two-way nesting and adaptive grid approaches need to be developed.

Improving model projections of the effect of climate change on air quality is contingent on improving projections of trends in regional air pollution meteorology. This is evident for PM, where differences between models appear to be driven principally by differences in precipitation (Pye et al., in press). Simulation of mixing depths and their trends is also subject to large uncertainty, as discussed in Section 2.

The effect of climate change on natural emissions needs to be better understood. Current model representations of the sensitivity of isoprene emission to climate change (based on temperature only) are clearly inadequate and yet have important implications for the simulated ozone response. Further work is needed to 
quantify the sensitivity of biogenic NMVOC emissions to changes in $\mathrm{CO}_{2}$ and land cover. Change in land cover may in the long term be the most important factor driving changes in biogenic NMVOC, methane, fire, and dust emissions.

Some aspects of ozone and PM chemistry relevant to the effect of climate change remain highly uncertain. We highlighted the uncertainty in isoprene chemistry, particularly in the formation and fate of isoprene nitrates. Uncertainty in organic PM formation, its temperature dependence, and its link to biogenic NMVOC emissions also needs to be addressed through laboratory and field studies. Production of ozone and PM in fire plumes is not well understood and will likely be of increasing relevance for air quality in the future.

Observed correlations of ozone and PM with meteorological variables offer a precious window into the effect of climate change. Their direct application to project future changes in air quality is subject to errors difficult to quantify, as discussed in Section 3. The correlations may be of most value for evaluating GCM-CTMs. Evaluation of GCM-CTMs has so far largely been limited to mean climatological statistics for ozone and PM, which are of little relevance for testing the model sensitivity to climate change. Reproducing observed correlations with meteorological variables (such as the ozone-temperature relationship) would be far more effective for building confidence in models.

Discerning directly the effect of climate change on air quality from long-term observation records of ozone and PM would obviously be of considerable interest, but concurrent trends in pollutant emissions represent probably an insurmountable impediment. A more promising avenue is to analyze long-term observed trends in meteorological variables relevant to air quality such as mixing depths, stagnation events, and the frequency of frontal passages. Records spanning several decades are available from assimilated meteorological data centers such as NCEP or ECMWF. As in all trend analyses using assimilated data, one must beware of artifact trends due to changes in the meteorological data being assimilated over the period of analysis.

The effect of climate change on air quality needs to be examined in concert with the effect of future changes in pollutant emissions. The latter are expected to change rapidly in the coming decades as a result of energy choices dictated by economic and climate concerns. Consistent projections of greenhouse gas and pollutant emissions for different socio-economic and policy scenarios, building on the IPCC SRES work of Nakicenovic et al. (2000), will be of great value to develop integrated frameworks for emission control policies that address both climate and air quality objectives. Quantifying the associated effect of climate change on air quality should be an important part of this policy development.

Finally, we briefly touched on the potential effect of climate change on mercury cycling, mostly to point out that mobilization of soil mercury as a result of increased respiration in boreal ecosystems could have major implications. Changes in ocean transport and volatilization of mercury are also of concern. No work so far has addressed these issues. A critical question is whether mercury bound to organic matter in soil will be released to the atmosphere or retained in the soil when that organic matter is respired. Volatilized mercury will be deposited elsewhere, and better understanding of this freshly deposited mercury in terms of bio-availability and formation of toxic methylmercury is needed. The same considerations apply to persistent organic pollutants (POPs), for which even less is known than for mercury.

\section{Acknowledgments}

We thank Shiliang Wu and Loretta J. Mickley (Harvard), as well as two anonymous reviewers for comments on the manuscript. DJJ was supported by the U.S. Environmental Protection Agency's STAR program through grants RD830959 and RD833370. Although this article has been reviewed by EPA and approved for publication, it does not necessarily represent EPA policies or views.

\section{References}

Arneth, A., Miller, P.A., Scholze, M., Hickler, T., Schurgers, G., Smith, B., Prentice, I.C., 2007. $\mathrm{CO}_{2}$ inhibition of global terrestrial isoprene emissions: potential implications for atmospheric chemistry. Geophys. Res. Lett. 34, L18813.

Avise, J., Chen, J., Lamb, B., Wiedimyer, C., Guenther, A., Salathe, E., Mass, C. Attribution of projected changes in U.S. ozone and $\mathrm{PM}_{2.5}$ concentrations to global changes. Atmos. Chem. Phys., submitted for publication.

Aw, J., Kleeman, M.J., 2003. Evaluating the first-order effect of intra-annual temperature variability on urban air pollution. J. Geophys. Res. 108, 4365

Baertsch-Ritter, N., Keller, J., Dommen, J., Prevot, A.S.H., 2004. Effects of various meteorological conditions and spatial emission resolutions on the ozone concentration and $\mathrm{ROG} / \mathrm{NO}_{x}$ limitation in the Milan area (I). Atmos. Chem. Phys. 4, 423-438.

Balkanski, Y.J., Jacob, D.J., Gardner, G.M., Graustein, W.M., Turekian, K.K., 1993. Transport and residence times of continental aerosols inferred from a global 3dimensional simulation of ${ }^{210} \mathrm{~Pb}$. J. Geophys. Res. 98, 20573-20586.

Bell, M.L., Goldberg, R., Hogrefe, C., Kinney, P.L., Knowlton, K., Lynn, B., Rosenthal, J., Rosenzweig. C., Patz, J.A., 2007. Climate change, ambient ozone, and health in 50 US cities. Climatic Change 82, 61-76.

Brasseur, G.P., Schultz, M., Granier, C., Saunois, M., Diehl, T., Botzet, T., Roeckner, E., Walters, S., 2006. Impact of climate change on the future chemical composition of the global troposphere. J. Clim. 19, 3932-3951.

Camalier, L., Cox, W., Dolwick, P., 2007. The effects of meteorology on ozone in urban areas and their use in assessing ozone trends. Atmos. Environ. 41, 7,127$7,137$.

Cardelino, C.A., Chameides, W.L., 1990. Natural hydrocarbons, urbanization, and urban ozone. J. Geophys. Res. 95, 13,971-13,979.

Centritto, M., Nascetti, P., Petrilli, L., Raschi, A., Loreto, F., 2004. Profiles of isoprene emission and photosynthetic parameters in hybrid poplars exposed to free-air $\mathrm{CO}_{2}$ enrichment. Plant Cell Environ. 27, 403-412.

Chen, J., Avise, J., Lamb, B. Salathe, E., Mass, C., Guenther, A., Wiedinmyer, C., Lamarque, J.-F., O'Neill, S., McKenzie, D., Larkin, N. The effects of global changes upon regional ozone pollution in the United States. Atmos. Chem. Phys., submitted for publication.

Cheng, C.S., Campbell, M., Li, Q., Li, G., Auld, H., Day, N., Pengelfly, D., Gingrich, S. Yap, D., 2007. A synoptic climatological approach to assess climatic impact on air quality in south-central Canada. Part II: future estimates. Water Air Soil Pollut. 182, 117-130.

Christensen, J.H., et al., 2007. Regional climate projections. In: Solomon, S. (Ed.), Climate Change 2007: The Physical Science Basis.Contribution of Working Group I to the Fourth Assessment Report of the Intergovernmental Panel on Climate Change. Cambridge University Press, Cambridge, UK and New York, NY, USA.

Cooper, O.R., Moody, J.L., Parrish, D.D., Trainer, M., Holloway, J.S., Ryerson, T.B., Hubler, G., Fehsenfeld, F.C., Oltmans, S.J., Evans, M.J., 2001. Trace gas signatures of the airstreams within North Atlantic cyclones: case studies from the North Atlantic Regional Experiment (NARE'97) aircraft intensive. J. Geophys. Res. 106, 5437-5456.

Cox, W.M., Chu, S.-H., 1995. Assessment of interannual ozone variation in urban areas from a climatological perspective. Atmos. Environ. 30, 2615-2625.

Dawson, J.P., Adams, P.J., Pandis, S.N., 2007a. Sensitivity of ozone to summertime climate in the Eastern USA: a modeling case study. Atmos. Environ. 41, 14941511.

Dawson, J.P., Adams, P.J., Pandis, S.N., 2007b. Sensitivity of $\mathrm{PM}_{2.5}$ to climate in the Eastern US: a modeling case study. Atmos. Chem. Phys. 7, 4,295-4,309.

Denman, K.L., et al., 2007. Couplings between changes in the climate system and biogeochemistry. In: Solomon, S. (Ed.), Climate Change 2007: The Physical Science Basis. Contribution of Working Group I to the Fourth Assessment Report of the Intergovernmental Panel on Climate Change. Cambridge University Press, Cambridge, United Kingdom and New York, NY, USA

Dentener, F.D., et al., 2006. The global atmospheric environment in the next generation. Environ. Sci. Technol. 40, 3586-3594.

Elminir, H.K., 2005. Dependence of urban air pollutants on meteorology. Sci. Total Environ. 350, 225-237.

Fiore, A.M., Jacob, D.J., Field, B.D., Streets, D.G., Fernandes, S.D., Jang, C., 2002. Linking ozone pollution and climate change: the case for controlling methane. Geophys. Res. Lett. 29, 1919.

Forkel, R., Knoche, R., 2006. Regional climate change and its impact on photooxidant concentrations in southern Germany: simulations with a coupled regional chemistry-climate model. J. Geophys. Res. 111, D12302.

Forkel, R., Knoche, R., 2007. Nested regional climate-chemistry simulations for central Europe. Compt. Rendus Geosci. 339, 734-746.

Forster, C., et al., 2001. Transport of boreal forest fire emissions from Canada to Europe. J. Geophys. Res. 106, 22,887-22,906.

Forster, P., et al., 2007. Changes in atmospheric constituents and in radiative forcing. In: Solomon, S. (Ed.), Climate Change 2007: The Physical Science Basis. Contribution of Working Group I to the Fourth Assessment Report of the Intergovernmental Panel on Climate Change. Cambridge University Press, Cambridge, United Kingdom and New York, NY, USA 
Giacopelli, P., Ford, K., Espada, C., Shepson, P.B., 2005. Comparison of the measured and simulated isoprene nitrate distributions above a forest canopy. J. Geophys. Res. 110, D01304.

Giorgi, F., Meleux, F., 2007. Modeling the regional effects of climate change on air quality. Compt. Rendus Geosci. 339, 721-733.

Guenther, A., Karl, T., Harley, P., Wiedinmyer, C., Palmer, P.I., Geron, C., 2006. Estimates of global terrestrial isoprene emissions using MEGAN (Model of Emissions of Gases and Aerosols from Nature). Atmos. Chem. Phys. 6, 3181-3210.

Guerova, G., Jones, N., 2007. A global model study of ozone distributions during the August 2003 heat wave in Europe. Environ. Chem. 4, 285-292.

Gustafson Jr., W.I., Leung, L.R., 2007. Regional downscaling for air quality assessment. Bull. Amer. Met. Soc. 88, 1215-1227.

Hauglustaine, D.A., Lathiere, J., Szopa, S., Folberth, G.A., 2005. Future tropospheric ozone simulated with a climate-chemistry-biosphere model. Geophys. Res. Lett. 32, L24807.

Heald, C.L., Jacob, D.J., Park, R.J., Alexander, B., Fairlie, T.D., Yantosca, R.M., Chu, D.A., 2006. Transpacific transport of Asian anthropogenic aerosols and its impact on surface air quality in the United States. J. Geophys. Res. 111, D14310.

Heald, C.L., Henze, D.K., Horowitz, L.W., Feddema, J., Lamarque, J.-F., Guenther, A. Hess, P.G., Vitt, F., Seinfeld, J.H., Goldstein, A.H., Fung, I., 2008. Predicted change in global secondary organic aerosol concentrations in response to future climate, emissions, and land use change. J. Geophys. Res. 113, D05211.

Heald, C.L., Wilkinson, M.J., Monson, R.K., Alo, C.A., Wang, G., Guenther, A. Response of isoprene emission to ambient $\mathrm{CO}_{2}$ changes and implications for global budgets. Global Change Biol., in press.

Held, I.M., Soden, B.J., 2000. Water vapor feedback and global warming. Annual Rev. Energy Environ. 25, 441-475.

Hogrefe, C., Lynn, B., Civerolo, K., Ku, J.-Y., Rosenthal, J., Rosenzweig, C., Goldberg, R., Gaffin, S., Knowlton, K., Kinney, P.L., 2004. Simulating changes in regional air pollution over the eastern United States due to changes in global and regional climate and emissions. J. Geophys. Res. 109, D22301.

Holloway, T., Fiore, A., Galanter Hastings, M., 2003. Intercontinental transport of air pollution: will emerging science lead to a new hemispheric treaty? Environ. Sci. Technol. 37, 4535-4542.

Horowitz, L.W., Fiore, A.M., Milly, G.P., Cohen, R.C., Perring, A., Woolridge, J.P., Hess, P.G., Emmons, L.K., Lamarque, J.-F., 2007. Observational constraints on the chemistry of isoprene nitrates over the eastern United States. J. Geophys. Res. 112, D12S08.

Jacob, D.J., Logan, J.A., Gardner, G.M., Yevich, R.M., Spivakovsky, C.M., Wofsy, S.C., 1993. Factors regulating ozone over the United States and its export to the global atmosphere. J. Geophys. Res. 98, 14,817-14,826.

Jacob, D.J., Horowitz, L.W., Munger, J.W., Heikes, B.G., Dickerson, R.R., Artz, R.S., Keene, W.C., 1995. Seasonal transition from $\mathrm{NO}_{x}$ - to hydrocarbon-limited ozone production over the eastern United States in September. J. Geophys. Res. 100, 9315-9324.

Jacobson, M.Z., 2007. Effects of ethanol (E85) versus gasoline vehicles on cancer and mortality in the United States. Environ. Sci. Technol. 41, 4150-4157.

Jacobson, M.Z., 2008. On the causal link between carbon dioxide and air pollution mortality. Geophys. Res. Lett. 35, L03809.

Johnson, C.E., Collins, W.J., Stevenson, D.S., Derwent, R.G., 1999. The relative roles of climate and emissions changes on future oxidant concentrations. J. Geophys. Res. 104, 18,631-18,645.

Kleeman, M.J., 2007. A preliminary assessment of the sensitivity of air quality in California to global change. Climatic Change 87, S273-S292.

Koch, D., Park, J., Del Genio, A., 2003. Clouds and sulfate are anticorrelated: a new diagnostic for global sulfur models. J. Geophys. Res. 108, 4781.

Kunkel, K.E., Huang, H.-C., Liang, X.-Z., Lin, J.-T., Wuebbles, D., Tao, Z., Williams, A. Caughey, M., Zhu, J., Hayhoe, K., 2007. Sensitivity of future ozone concentrations in the northeast USA to regional climate change. Mitig. Adapt. Strat. Glob. Change. doi:10.1007/s11027-007-9137-y.

Lambert, S.J., Fyfe, J.C., 2006. Changes in winter cyclone frequencies and strengths simulated in enhanced greenhouse warming experiments: results from the models participating in the IPCC diagnostic exercise. Clim. Dyn. 26, 713-728.

Langner, J., Bergstrom, R., Foltescu, V., 2005. Impact of climate change on surface ozone and deposition of sulphur and nitrogen in Europe. Atmos. Environ. 39, $1,129-1,141$.

Leibensperger, E.M., Mickley, L.J., Jacob, D.J. Sensitivity of U.S. air quality to midlatitude cyclone frequency and implications of 1980-2006 climate change. Atmos. Chem. Phys., submitted for publication.

Leung, L.R., Gustafson, W.I., 2005. Potential regional climate change and implications to U.S. air quality. Geophys. Res. Lett. 32, L16711.

Li, O., Jacob, D.J., Park, R., Wang, Y., Heald, C.L., Hudman, R., Yantosca, R.M., Martin, R.V., Evans, M., 2005. North American pollution outflow and the trapping of convectively lifted pollution by upper-level anticyclone. J. Geophys. Res. 110, D10301.

Liang, J., Horowitz, L.W., Jacob, D.J., Wang, Y., Fiore, A.M., Logan, J.A., Gardner, G.M. Munger, J.W., 1998. Seasonal variations of reactive nitrogen species and ozone over the United States, and export fluxes to the global atmosphere. J. Geophys. Res. 103, 13,435-13,450.

Liang, X.-Z., Pan, J., Zhu, J., Kunkel, K.E., Wang, J.X.L., Dai, A., 2006. Regional climate model downscaling of the U.S. summer climate and future change. J. Geophys. Res. 111, D10108.

Liao, H., Chen, W.-T., Seinfeld, J.H., 2006. Role of climate change in global predictions of future tropospheric ozone and aerosols. J. Geophys. Res. 111, D12304.

Liao, K.-J., Tagaris, E., Manomaiphiboon, K., Napelenok, S.-L., Woo, J.-H., He, S., Amar, P., Russell, A.G., 2007. Sensitivities of ozone and fine particulate matter formation to emissions under the impact of potential future climate change. Environ. Sci. Technol. 41, 8355-8361.

Lin, C.-Y.C., Jacob, D.J., Fiore, A.M., 2001. Trends in exceedances of the ozone air quality standard in the continental United States, 1980-1998. Atmos. Environ. 35, 3217-3228.

Lin, C.-Y.C., Mickley, L.J., Hayhoe, K., Maurer, E.P., Hogrefe, C. Rapid Calculation of Future Trends in Ozone Exceedances Over the Northeast United States : Results From Three Models and Two Scenarios, Presented at the Consequences of Global Change for Air Quality Festival, EPA, Research Triangle Park, NC, February 20-21, 2007.

Lin, J.-T., Patten, K.O., Hayhoe, K., Liang, X.-Z., Wuebbles, D.J., 2008a. Effects of future climate and biogenic emissions changes on surface ozone over the United States and China. J. Appl. Meteor. Climatol. 47, 1888-1909.

Lin, J.-T., Patten, K.O., Liang, X.-Z., Wuebbles, D.J., 2008b. Effects of intercontinenta transport on surface ozone over the United States at the present and future. Geophys. Res. Lett. 35, L02805.

Liu, H.Y., Jacob, D.J., Bey, I., Yantosca, R.M., Duncan, B.N., Sachse, G.W., 2003. Transport pathways for Asian combustion outflow over the Pacific: interannual and seasonal variations. J. Geophys. Res. 108, 8786.

Liu, S.C., Trainer, M., Fehsenfeld, F.C., Parrish, D.D., Williams, E.J., Fahey, D.W. Hubler, G., Murphy, P.C., 1987. Ozone production in the rural troposphere and the implications for regional and global ozone distributions. J. Geophys. Res. 92, 4191-4207.

Logan, J.A., 1999. An analysis of ozonesonde data for the troposphere: recommendations for testing 3-D models, and development of a gridded climatology for tropospheric ozone. J. Geophys. Res. 104, 16115-16149.

McCabe, G.J., Clark, M.P., Serreze, M.C., 2001. Trends in northern hemisphere surface cyclone frequency and intensity. J. Clim. 14, 2763-2768.

Meleux, F., Solmon, F., Giorgi, F., 2007. Increase in European summer ozone amounts due to climate change. Atmos. Environ. 41, 7,577-7,587.

Mickley, L.J., Jacob, D.J., Field, B.D., Rind, D., 2004. Effects of future climate change on regional air pollution episodes in the United States. Geophys. Res. Lett. 30, L24103.

Monson, R.K., et al., 2007. Isoprene emission from terrestrial ecosystems in response to global change: minding the gap between models and observations. Phil. Trans. R. Soc. A 365, 1677-1695.

Morris, R.E., Gery, M.S., Liu, M.K., Moore, G.E., Daly, C., Greenfield, S.M., 1989 Sensitivity of a regional oxidant model to variation in climate parameters. In: Smith, J.B., Tirpak, D.A. (Eds.), The Potential Effects of Global Climate Change on the United States. US Environmental Protection Agency, Office of Policy, Planning and Evaluation, Washington DC.

Murazaki, K., Hess, P., 2006. How does climate change contribute to surface ozone change over the United States? J. Geophys. Res. 111, D05301.

Nakicenovic, N., et al., 2000. IPCC Special Report on Emissions Scenarios. Cambridge University Press, Cambridge, UK and New York, NY.

Nolte, C.G., Gilliland, A.B., Hogrefe, C., Mickley, L.J., 2008. Linking global to regional models to assess future climate impacts on surface ozone levels in the United States. J. Geophys. Res. 113, D14307.

Ordonez, C., Mathis, H., Furger, M., Henne, S., Hoglin, C., Staehelin, J., Prevot, A.S.H., 2005. Changes of daily surface ozone maxima in Switzerland in all seasons from 1992 to 2002 and discussion of summer 2003. Atmos. Chem. Phys. 5, 11871203.

Paulot, F., Crounse, J.D., Kjaergaard, H.G., Kroll, J.H., Seinfeld, J.H., Wennberg, P.O., 2008. Isoprene photooxidation mechanism: resonance channels and implications for the production of nitrates and acids. Atmos. Chem. Phys. Discuss. 8 , $14643-14716$

Prospero, J.M., 1999. Long-term measurements of the transport of African mineral dust to the southeastern United States: implications for regional air quality. J. Geophys. Res. 104, 15917-15927.

Pye, H.O.T., Seinfeld, J.H., Liao, H., Wu, S., Mickley, L.J., Jacob, D.J. Effects of changes in climate and emissions on future sulfate-nitrate-ammonium aerosol levels in the United States. J. Geophys. Res., in press.

Racherla, P.N., Adams, P.J., 2006. Sensitivity of global tropospheric ozone and fine particulate matter concentrations to climate change. J. Geophys. Res. 111, D24103.

Raich, J.W., Schlesinger, W.H., 1992. The global carbon dioxide flux in soil respiration and its relationship to vegetation and climate. Tellus 44B, 81-99.

Rao, S.T., Ku, J.Y., Berman, S., Zhang, K., Mao, H., 2003. Summertime characteristics of the atmospheric boundary layer and relationships to ozone levels over the eastern United States. Pure Appl. Geophys. 160, 21-55.

Ravichandran, M., 2004. Interaction between mercury and dissolved organic mater - a review. Chemosphere 55, 319-331.

Rind, D., Lerner, J., McLinden, C., 2001. Changes of tracer distribution in the doubled CO2 climate. J. Geophys. Res. 106, 28,061-28,080.

Rubin, J.I., Kean, A.J., Harley, R.A., Millet, D.B., Goldstein, A.H., 2006. Temperature dependence of volatile organic compound evaporative emissions from moto vehicles. J. Geophys. Res. 111, D03305.

Sanchez-Ccoyllo, O.R., Ynoue, R.Y., Martins, L.D., Andradede, M. de F., 2006. Impacts of ozone precursor limitation and meteorological variables on ozone concentration in Sao Paulo, Brazil. Atmos. Environ. 40, S552-S562.

Sanderson, M.G., Jones, C.D., Collins, W.J., Johnson, C.E., Derwent, R.G., 2003. Effect of climate change on isoprene emissions and surface ozone levels. Geophys. Res. Lett. 30, 1936.

Selin, N.E., Jacob, D.J., Yantosca, R.M., Strode, S., Jaegle, L., Sunderland, E.M., 2008 Global 3-D land-ocean-atmosphere model for mercury: present-day vs. preindustrial cycles and anthropogenic enrichment factors for deposition. Global Biogeochem. Cy. 22, GB2011. 
Sheehan, P.E., Bowman, F.K., 2001. Estimated effects of temperature on secondary organic aerosol concentrations. Environ. Sci. Technol. 35, 2129-2135.

Sillman, S., Samson, P.J., 1995. The impact of temperature on oxidant formation in urban, polluted rural and remote environments. J. Geophys. Res.100,11497-11508.

Solberg, S., Hov, O., Sovde, A., Isaksen, I.S.A., Coddeville, P., De Backer, H., Forster, C. Orsolini, Y., Uhse, K., 2008. European surface ozone in the extreme summer 2003. J. Geophys. Res. 113, D07307.

Spracklen, D.V., Logan, J.A., Mickley, L.J., Hudman, R.C., Flannigan, M.D., Westerling, A.L. Prediction of the impact of climate change on wildfire and carbonaceous aerosol in the western United States. J. Geophys. Res., submitted for publication.

Steiner, A.L., Tonse, S., Cohen, R.C., Goldstein, A.H., Harley, R.A., 2006. Influence of future climate and emissions on regional air quality in California. J. Geophys. Res. 111, D18303.

Strode, S.A., Jaegle, L., Selin, N.E., Jacob, D.J., Park, R.J., Yantosca, R.M., Mason, R.P., Slemr, F., 2007. Air-sea exchange in the global mercury cycle. Global Biogeochem. Cy. 21, GB1017.

Sunderland, E.M., Mason, R.P., 2007. Human impacts on open ocean mercury concentrations. Global Biogeochem. Cy. 21, GB4022.

Tagaris, E., Manomaiphiboon, K., Liao, K.-J., Leung, L.R., Woo, J.-H., He, S., Amar, P. Russell, A.G., 2007. Impacts of global climate change and emissions on regional ozone and fine particulate matter concentrations over the United States. J. Geophys. Res. 112, D14312.

Tao, Z., Williams, A., Huang, H.C., Caughey, M., Liang, X.-Z., 2007. Sensitivity of U.S. surface ozone to future emissions and climate changes. Geophys. Res. Lett. 34 L08811.

Tsigaridis, K., Kanakidou, M., 2007. Secondary organic aerosol importance in the future atmosphere. Atmos. Environ. 41, 4682-4692.

Turetsky, M.R., Harden, J.W., Friedli, H.R., Flannigan, M., Payne, N., Crock, J., Radke, L., 2006. Wildfires threaten mercury stocks in northern soils. Geophys. Res. Lett. 33, L16403.
Unger, N., Shindell, D.T., Koch, D.M., Amann, M., Cofala, J., Streets, D.G., 2006. Influences of man-made emissions and climate changes on tropospheric ozone, methane, and sulfate at 2030 from a broad range of possible futures. J. Geophys. Res. 111, D12313.

United Nations Economic Comission for Europe, 2007. Hemispheric Transport of Air Pollution 2007. Air Pollution Studies No. 16. United Nations, New York and Geneva.

Vautard, R., Honoré, C., Beekman, M., Rouil, L., 2005. Simulation of ozone during the August 2003 heat wave and emission control scenarios. Atmos. Environ. 29, 2957-2967.

Vautard, R., Beekman, M., Desplat, J., Hodzic, A., Morel, S., 2007. Air quality in Europe during the summer of 2003 as a prototype of air quality in a warmer climate. Compt. Rendus Geosci. 339, 747-763.

Weaver, C.P., et al. A preliminary synthesis of modeled climate change impacts on U.S. regional ozone concentrations. Bull. Amer. Met. Soc., submitted for publication.

Wise, E.K. Climate-based sensitivity of air quality to climate change scenarios for the southwestern United States. Int. J. Clim., in press.

Wise, E.K., Comrie, A.C., 2005. Meteorologically adjusted urban air quality trends in the Southwestern United States. Atmos. Environ. 39, 2969-2980.

Wu, S., Mickley, L.J., Leibensperger, E.M., Jacob, D.J., Rind, D., Streets, D.G., 2008a. Effects of 2000-2050 global change on ozone air quality in the United States. J. Geophys. Res. 113, D06302.

Wu, S., Mickley, L.J., Jacob, D.J., Rind, D., Streets, D.G., 2008b. Effects of 2000-2050 changes in climate and emissions on global tropospheric ozone and the policy-relevant background ozone in the United States. J. Geophys. Res. 113, D18312.

Zishka, K.M., Smith, P.J., 1980. The climatology of cyclones and anticyclones over North America and surrounding ocean environs for January and July, 19501977. Mon. Weather Rev. 108, 387-401. 